\title{
Evaluación in vitro del efecto promotor del crecimiento en plántulas de chía
}

Gómez Molina ${ }^{1}$, Silvia, Krieger, Susana ${ }^{1}$, Curti, Ramiro ${ }^{2}$, Herrando ${ }^{1}$, Carlos y Aldana, Alexia ${ }^{1}$

${ }^{1}$ Universidad Nacional de Salta, Argentina.

${ }^{2}$ Laboratorio de Investigaciones Botánicas (LABIBO), Facultad de Ciencias Naturales y Sede Regional Sur, Universidad Nacional de Salta-CONICET, Salta, Argentina

Introducción: El crecimiento de las planta se ve incrementado por la actividad de los microorganismos promotores del crecimiento vegetal que colonizan las raíces. Entre otros mecanismos de acción estos microorganismos estimulan la germinación y mejoran el desarrollo de las plántulas. Especies de los géneros Pseudomonas spp. y Bacillus spp. aisladas de las raíces tienen efecto promotor de crecimiento en las semillas de papa, maíz, soja, canola, trigo y garbanzo. Una alternativa para promover el crecimiento de las plántulas es la inoculación con rizobacterias como una forma de reducir las dosis de fertilizantes químicos. El objetivo del trabajo fue evaluar in vitro el efecto promotor de las bacterias en estudio sobre el crecimiento de plántulas de chía.

Materiales y métodos: En el ensayo se trabajó con un consorcio (CO) y con cepas aisladas de la rizosfera de chía, tabaco y compost identificadas como Pseudomonas: Ps chía, Ps.2, Ps.Ba y Bacillus cereus, Bacillus subtilis y Bacillus sp. Se desinfectaron las semillas de chía con hipoclorito de sodio al $1 \%$ y se lavaron con agua destilada estéril. La inoculación de semillas se realizó sumergiéndolas en los diferentes caldos bacterianos, durante 45 minutos y se colocaron en placas Petri con agar agua (2\%).

Para evaluar el efecto de los tratamientos Ps chía, Ps.2, Ps.Ba, Bacillus cereus, Bacillus subtilis y Bacillus sp. se realizó un experimento bajo un diseño completamente aleatorizado (DCA) con tres repeticiones. Se realizó un análisis de la varianza y se compararon las medias entre los distintos tratamientos mediante la aplicación del test de Mínima Diferencia Significativa de Fisher (LSD).

Resultados: En la longitud del tallo se detectaron diferencias significativas $(\mathrm{p}<0,05)$ entre todos los tratamientos y el testigo. Ps. Ba, Bacillus sp, CO y Ps.2 aumentaron la longitud del tallo de las plántulas en un $74 \%$. Se detectaron diferencias significativas $(\mathrm{p}<0,05)$ en la longitud de la raíz con respecto al testigo en los siguientes tratamientos Ps.Ba, Ps.2 y CO, incrementando la longitud radicular un 22\%.Las bacterias $P s \mathrm{Ba}, \mathrm{CO}$ y $P s 2$ tuvieron un efecto conjunto sobre la longitud de la raíz y del tallo.

Conclusiones: De acuerdo con los resultados podemos concluir que las rizobacterias aisladas de raíces de cultivos representan una alternativa viable para promover el crecimiento de las plántulas de chía con el objetivo de favorecer su establecimiento. Futuros estudios deberían evaluar si las condiciones desarrolladas in vitro son factibles de ser aplicadas a campo. 